\title{
Mathematical modeling of the heating process in a vortex tube at the gas distribution stations
}

\author{
Labay V. Y., Savchenko O. O., Zhelykh V. M., Kozak Kh. R. \\ Department of Heat, Gas Supply and Ventilation, \\ Institute of Building and Environmental Engineering, \\ Lviv Polytechnic National University, \\ 12 S. Bandera Str., 79013, Lviv, Ukraine
}

(Received 8 March 2019; Revised 4 May 2019; Accepted 20 June 2019)

\begin{abstract}
In all sectors of the national economy of Ukraine, issues of energy efficiency and saving of fuel and energy resources are important. Legislative changes in the branches and scientific developments of scientists allow reducing the energy dependence of Ukraine on imported fuels. One of the energy-saving measures for the transportation of natural gas is the use of a vortex tube for heating natural gas at gas distribution stations. Natural gas is heated before the process of reducing it in the gas pressure regulator to prevent the formation of crystalline hydrates within the gas pressure regulator. The complexity of the implementation of such a measure is the explosion of the fire hazard of natural gas, which makes it impossible to conduct a sufficient number of experimental studies to determine the required characteristics of the vortex tube for operation at the gas distribution station. Therefore, for the wide introduction of a vortex tube at gas distribution stations, a generalized mathematical model should be developed that would allow describing the process of heating the vortex tube of a working gas with different thermophysical parameters. In this paper, the thermodynamic and physical bases of the process of heating the compressed gases in the vortex tube are considered and the main parameters that influence the operation of the vortex tube are determined. The mathematical model of the process of heating the natural gas in a vortex tube is scientifically substantiated and improved. To improve the mathematical model of the natural gas heating process in the vortex tube, loss of dynamic pressure was determined on each characteristic section of the vortex tube and the degree of heating therein. Moreover, the mathematical model proposed by the authors allows us to determine the thermal power of the vortex tube and the amount of heat needed to heat the working gas in the vortex tube.
\end{abstract}

Keywords: heating process, vortex tube, gas distribution station, natural gas.

2000 MSC: $80 \mathrm{~A} 10 ; 80 \mathrm{~A} 20 ; 82 \mathrm{C} 40$

UDC: $621.6-032.31$

DOI: $10.23939 / \mathrm{mmc} 2019.02 .311$

\section{Introduction}

In 1994, the law "On Energy Saving" was signed in Ukraine, which should encourage enterprises, organizations and citizens to save energy, introduce energy-saving technologies, use of low energyconsuming equipment and alternative energy sources. However, at present and beyond, there is the irrational use of fuel and energy resources and insufficient implementation of alternative energy sources in the energy sector of Ukraine [1].

The main sources of primary energy use in the world are transport $(28 \%)$, industry $(32 \%)$ and housing and communal sector $(40 \%)$ [2]. In Ukraine, in the housing and communal sector, increasing the energy efficiency of new and already built houses is on the legislative level. Scientists are developing new energy-saving technologies for heating, ventilation and air conditioning [3,4]. At the same time, the concepts of "passive", "active" and "zero energy" buildings are being implemented, the designs and 
equipment of which not only allow to save primary energy, but also generate energy for own needs, which makes such buildings independent of external powers supply $[5,6]$.

Natural gas is one of the main sources of primary energy in Ukraine. The share of its consumption in the total consumption of primary energy is more than $30 \%$, and its cost is constantly increasing. The cost of natural gas during its use as a source of energy in industry directly affects the components of the cost price of industrial goods, therefore reducing the consumption of natural gas at industrial plants, CHP plants, boiler houses will not only allow Ukraine to gain energy independence, but also reduce the cost of the said products. Although natural gas consumption has decreased by 6 billion $\mathrm{m}^{3}$ over the past 3 years [7], but industrial, housing and communal services, and enterprises of the gas-extracting and gas-transport sector have the potential for economical use and reduction of overall consumption.

Enterprises of the gas-extracting and gas-transport sector lose natural gas during its transportation by gas distribution and in-house networks, the implementation of preventive works and ongoing repairs, for the needs of heating, hot water supply, and ventilation of the premises of the said enterprises. The annual volume of such natural gas losses is estimated at 2 billion $\mathrm{m}^{3}$ [8].

One of the measures to reduce natural gas consumption for the own needs of gas transport companies is the use of energy-saving and energy-efficient equipments for heating natural gas before the pressure regulator at gas distribution stations. To this end, it is advisable to use a vortex tube, which allows without the use of additional energy sources to heat natural gas to the required temperature.

\section{Analysis of literary data and problem formulation}

The successful use of the vortex tube finds its place in various industries. The first attempts to use it were in air conditioning systems for freezing and deep cooling of air. Later, the vortex tube began to be used to cool and remove valuable products from purge gases of chemical plants, to cool natural gas and purify it from liquid contaminants. The presence of a heated stream allows using a vortex tube to heat gases at both normal and elevated temperatures. Such a wide range of applications of a vortex tube is due to the peculiarities of the work process and the design of the apparatus. In a vortex tube, it is possible to simultaneously carry out several processes, such as cooling and heating, draining or cleaning gas. The working gas of the vortex tube can be practically any gas or a mixture of gases. The pressures and quantities of the working gas and produced flows can be varied. The source of the compressed working gas can be located at a considerable distance from the object. In addition, the advantages of vortex tubes are small size and weight, ease of construction, lack of moving parts, short start-up period, low cost of manufacturing and ease of maintenance $[9,10]$.

The presence of opposing opinions about the physical nature of this phenomenon and the absence of the theory of the distribution of gas flow in the vortex tube demanded to carry out a large number of studies to verify the influence of individual structural elements on the efficiency of the distribution of the working gas in the tube. In the course of the research, the basic characteristics of the tube's efficiency were removed and the change in flow parameters was determined: velocity, pressure, the temperature in sections and the length of the tube.

Consequently, based on the analysis of available literature data, a vortex tube can be used to heat natural gas before the gas pressure regulator at gas distribution stations, which will reduce the losses of natural gas to their own needs by gas transport companies. However, for the possibility of generalizing the results of the vortex tube operation for different working gases, it is necessary to improve the mathematical model of the heating process in the vortex tube.

\section{The purpose and objectives of the study}

The purpose of this work is to improve the mathematical model of the heating process in a vortex tube.

To achieve this purpose, the following main tasks were formulated:

Mathematical Modeling and Computing, Vol. 6, No. 2, pp. 311-319 (2019) 
- to consider the thermodynamic and physical bases of the process of heating the compressed gases in a vortex tube;

- to scientifically substantiate and improve the mathematical model of heating in a vortex tube.

\section{Methods, materials and research results}

In this work, the object of the study is a vortex tube, the general form of which is shown in Fig. 1. For the first time the work was investigated and the patented vortex tube scheme was in 1934 by George J. Ranque [11].

The work of the vortex tube is the following. The compressed working gas is fed through the tangential nozzle channel 3 to the pipe 4, where intense circular motion is established. During this, there arises an uneven field of temperature. Layers of gas near the axis of the pipe are colder than the inlet gas, and the peripheral layers of the swirled stream are hotter. A part of the gas as a cold stream is removed through the diaphragm 2 , and the other part, such as the heated gas, through the throttle valve 5 is removed from the other side of the tube. The gradual closing of the throttle valve 5 increases the overall pressure in the vortex tube and the quantity of cold flow through the aperture of the diaphragm 2 with a corresponding reduction in the quantity of hot flow. The temperatures the

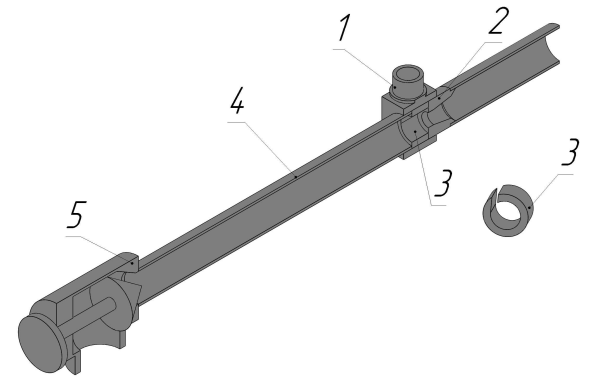

Fig. 1. General view of the vortex tube: 1 is case; 2 is diaphragm; 3 is nozzle channel; 4 is pipe; 5 is throttle valve. cold and heated flows also change during this.

The main thermophysical characteristics of the vortex tube in the process of heating the working gas are:

- the temperature of the working gas at the entrance to the vortex tube $t_{\text {ent }}$;

- temperature of the working gas at the outlet after the throttle valve (the heated flow after of the vortex tube) $t_{h}$;

- heating degree of the working gas after the vortex tube $\Delta t_{h}=t_{h}-t_{\text {ent }}$;

- quantity of working gas at the entrance to the vortex tube $G_{\text {ent }}$;

- quantity of working gas at the outlet after the throttle valve (the heated flow after of the vortex tube) $G_{h}$;

- the share of the heated flow the working gas in the vortex tube $\varepsilon=\frac{G_{h}}{G_{\text {ent }}}$.

The vortex tube is installed at the gas distribution station (Fig. 2) before the gas pressure regulator for heating natural gas. The heating of natural gas before the gas pressure regulator is carried out to prevent the formation of crystalline hydrates inside the gas pressure regulator in the process of reducing pressure the natural gas from the gas pressure in the main gas pipeline $(1.2-10 \mathrm{MPa})$ to the gas pressure in the distribution gas pipeline $(0.6-1.2 \mathrm{MPa})$.

The gas distribution station with a vortex tube works like this [12]. The gas flow from the main gas pipeline 1 passes through the shut-off valves 2 and 4 to the entrance of the working gas 3. During this,

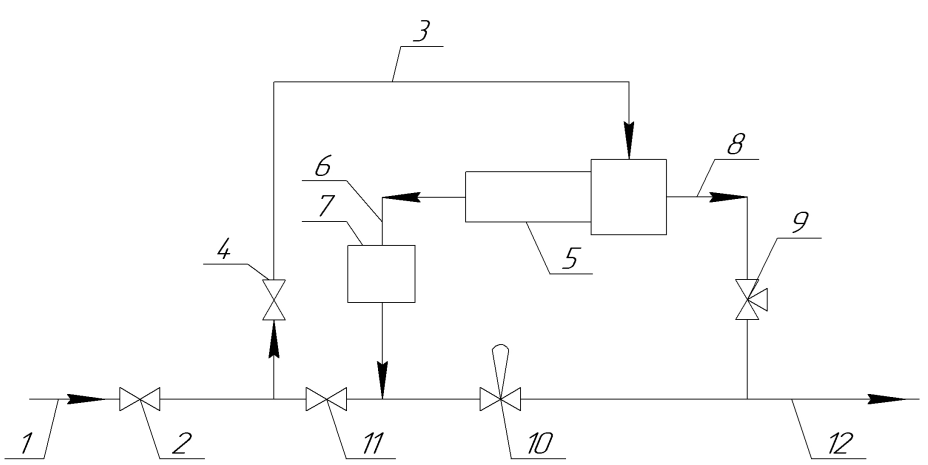

Fig. 2. Scheme of the technological thread of the gas distributing station with a vortex tube: 1 is main gas pipeline; 2, 4, 11 are shut-off valves; 3 is entrance of the working gas; 5 is vortex tube; 6 is pipeline of the heated gas flow; 7 is separator; 8 is pipeline of cold gas flow; 9 is safety shut-off valve; 10 is gas pressure regulator; 12 is distribution gas pipeline. 
the shut-off valve 11 is closed. After separating the gas flow by two, the heated stream through the pipeline 6 after the separator 7 enters the gas pressure regulator 10. The cold flow through the pipeline 8 through the safety shut-off valve 9 enters the distribution gas pipeline 12 after the gas pressure regulator. Reducing pressure the heated natural gas avoids the formation of crystalline hydrates in the middle of the gas pressure regulator and accordingly ensures the reliability of gas supply. The throttle valve of the vortex tube in this scheme of the gas distribution station is set to the specified quantity of the heated stream.

One of the biggest problems during the design of a vortex tube for their operation at gas distribution stations is the lack of a method for calculating vortex tubes operating on natural gas of high pressure. Experimental studies of existing gas distributing stations require a significant amount of experiments to determine the optimal characteristics of the vortex tube, which are dangerous due to the explosive nature of natural gas.

The process of heating natural gas before the process of throttling at gas-distribution stations is a complex task, the solution of which depends on many factors. Therefore, for the development of a mathematical model, the following basic simplifications and assumptions are introduced, which, as shown by the following analysis, are permissible and do not cause significant errors.

1. The vortex tube is not further cooled, so it is adiabatic. This means that a heat balance must be observed with full heat:

$$
G_{\text {ent }} i_{\text {ent }}=G_{c} i_{c}+G_{h} i_{h}
$$

where $i_{e n t}, i_{c}, i_{h}$ are enthalpy, respectively, of the entrance, cold and heated flows of the working gas.

Divide the two parts of this equation into $G_{e n t}$ :

$$
i_{\text {ent }}=(1-\varepsilon) i_{c}+\varepsilon i_{h},
$$

where $\varepsilon$ is share of heated flow.

If you enter the notations $\Delta i_{c}=i_{c}-i_{\text {ent }}$ and $\Delta i_{h}=i_{h}-i_{\text {ent }}$, then the equation (2) can be written as:

$$
0=(1-\varepsilon) \Delta i_{c}+\varepsilon \Delta i_{h}
$$

2. When constructing a mathematical model of the natural gas heating process in a vortex tube, it is necessary to take into account the decrease in temperature due to the Joule-Thomson throttle effect. Natural gas transported by main gas pipelines consists mainly of methane (98\%). In the interval of change in pressure and temperature, characteristic for the transportation of natural gas, the increase in the enthalpy of higher hydrocarbons beyond the phase transition makes a small contribution to the overall change in the enthalpy of the mixture. Therefore, the change in the enthalpy of the mixture:

$$
\Delta i=\Delta i^{\prime}-n \cdot r,
$$

where $\Delta i^{\prime}$ is change in the methane enthalpy; $n \cdot r$ is change in enthalpy for phase transition; $n$ is mass concentration of condensed gas; $r$ is hidden heat of evaporation.

Using the equation (4), equality (3) can be presented in the form:

$$
(1-\varepsilon) \Delta i_{c}^{\prime}+\varepsilon \Delta i_{h}^{\prime}=(1-\varepsilon) n_{c} r+\varepsilon n_{h} r,
$$

where $n_{c}, n_{h}$ are mass concentrations of condensate in cold and heated gas flows, $r$ is some average heat of evaporation.

At $\varepsilon=0$ and $\varepsilon=1$, there is actually a simple gas throttling. During this, a certain amount of condensate falls out and the right side (5) must be different from zero. However, its numerical value is very small, since the total concentration of higher hydrocarbons in the gas source is small. By reducing $\varepsilon$ the heated stream is enriched with higher hydrocarbons. This is due to the following reasons. The gas in the inlet nozzles moves almost with the sound velocities, as a result of which its thermodynamic temperature is significantly reduced. Therefore, most heavy hydrocarbons pass into the liquid phase 
at the entrance to the vortex tube. The condensate droplets formed by centrifugal forces are thrown into the periphery of the vortex tube into the place where the heated flow is formed. An increase in the concentration of higher hydrocarbons in the heated flow leads to an increase in the concentration of the liquid phase $n_{h}$, which separates from the heated stream.

The cold gas flow is formed in the axial part of the vortex tube, so the concentration of heavy hydrocarbons in this stream is negligible. It is always less than the concentration of heavy hydrocarbons in the inlet stream, reaching this value only for $\varepsilon=0$. It follows from this that the relative quantity of condensate falling out in the cold flow $n_{c}$ is very small:

$$
(1-\varepsilon) \Delta i_{c}^{\prime}+\varepsilon \Delta i_{h}^{\prime}=\varepsilon n_{h} r .
$$

The concentration of heavy hydrocarbons, and with it, and the magnitude $n_{h}$, monotonously increases in the reduction of the proportion of heated stream $\varepsilon$. Therefore, the product $\varepsilon n_{h}$ reaches a maximum value for some intermediate value $\varepsilon$. Thus, the entire right side of (6) should have a maximum at average values $\varepsilon$. If we assume that the quantity of condensation that has fallen out can be neglected then we will have:

$$
n_{0}=\varepsilon n_{h} .
$$

3. The pipe of the vortex tube is cylindrical.

4. The most rational is the tangential input with a rectangular nozzle [13], and for each individual case, the optimal nozzle should have a precisely defined cross-sectional area $f_{n}$. The pipe diameter of the vortex tube $d_{p}$ depends on the quantity of gas coming through the nozzle, and, accordingly, from the area of the nozzle. The values of these factors was pre-determined from the condition of gas heating:

$$
f_{n}=\frac{G_{e n t} \cdot a_{c r}}{k \cdot p_{c r} \cdot p_{e n t}}
$$

where $G_{\text {ent }}$ is seconds quantity of the working gas, $\mathrm{kg} / \mathrm{s} ; a_{c r}$ is critical velocity at absolute temperature of the inlet flow $T_{\text {ent }}$, gas constant $R$, adiabatic index $k$ :

$$
a_{c r}=\sqrt{\frac{2 k}{k+1} R} \cdot \sqrt{T_{\text {ent }}} ;
$$

$p_{c r}$ is relative pressure at critical speed, $p_{\text {ent }}$ is input flow pressure.

5 . The temperatures and pressures of the gas at the entrance to the vortex tube and the pressures of the output hot and cool flows were maintained at the certain given values.

6 . The practical value of the required degree of heating at the gas distribution stations should be $\Delta t_{h}^{g}=4 \div 6{ }^{\circ} \mathrm{C}[14]$.

7. Since the gas distribution stations have constant design sizes of standard designs, there is an appropriate restriction on the size of the vortex tube for them to be installed.

In order to improve the mathematical model of the natural gas heating process in the vortex tube, loss of dynamic pressure was determined on each characteristic part of the vortex tube

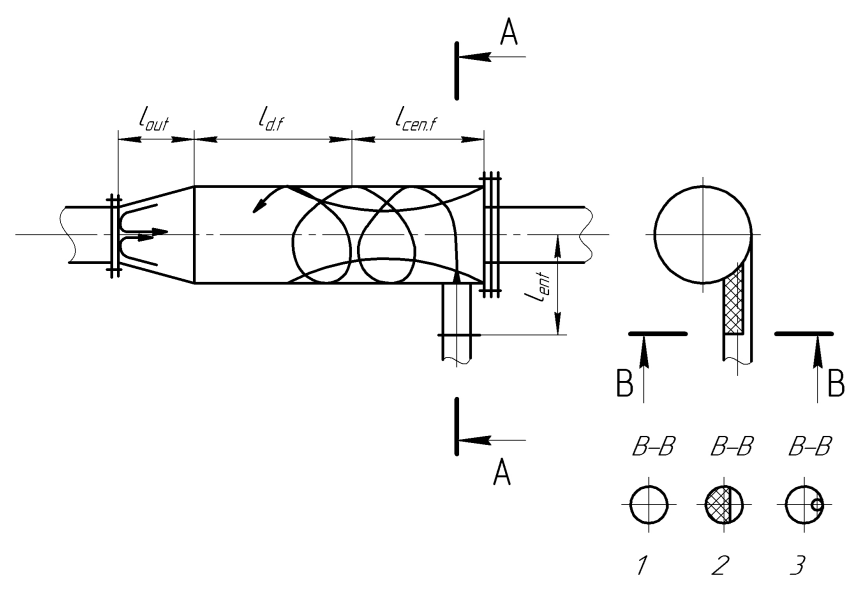

Fig. 3. Hydraulic scheme of a vortex tube: 1, 2, 3 are types of inlet branch tubes. and the heating degree in it (Fig. 3).

Hydraulic resistance of the vortex tube consists of the following quantities:

$$
\Delta P=\Delta P_{\text {ent }}+\Delta P_{\text {cen.f }}+\Delta P_{d . f}+\Delta P_{\text {out }},
$$

Mathematical Modeling and Computing, Vol. 6, No. 2, pp. 311-319 (2019) 
where $\Delta P_{\text {ent }}$ is hydraulic resistance of flow at the entrance in the vortex tube; $\Delta P_{\text {cen.f }}$ is hydraulic resistance of the centrifugal flow section; $\Delta P_{d . f}$ is hydraulic resistance of the section of the developed flow in the vortex tube; $\Delta P_{\text {out }}$ is hydraulic resistance to the outlet of the vortex tube.

Hydraulic resistance of flow at the entrance in the vortex tube:

$$
\Delta P_{\mathrm{ent}}=a\left(\frac{l_{\text {ent }}}{d_{\text {ent }}}\right)^{n} \cdot \bar{w}_{\text {ent }}^{2},
$$

where $a$ is experimental parameter, $\mathrm{N} \cdot \mathrm{s}^{2} / \mathrm{m}^{4} ; n$ is degree indicator, which depends on the type of design of the inlet branch pipe; $d_{\text {ent }}$ is hydraulic diameter of the inlet (nozzle), $\mathrm{m}$; $l_{\text {ent }}$ is length of the inlet (nozzle), $\mathrm{m} ; \bar{w}_{\text {ent }}$ is average speed flow at the entrance, $\mathrm{m} / \mathrm{s}$.

The values of the parameter $a$ and the degree indicator $n$ for different constructures of the inlet branch pipes are shown in Table 1.

Table 1. The values of the parameter $a$ and degree indicator $n$ for different constructures of the inlet branch pipes of the vortex tube.

\begin{tabular}{|c|c|c|c|}
\hline Constructures of the inlet branch tube & 1 & 2 & 3 \\
\hline Parameter $a, \mathrm{~N} \cdot \mathrm{s}^{2} / \mathrm{m}^{4}$ & 131.6 & 142.0 & 156.0 \\
\hline Degree indicator $n$ & 1.05 & 0.33 & 0.25 \\
\hline
\end{tabular}

Hydraulic resistance to the outlet of the vortex tube:

$$
\Delta P_{\text {out }}=b\left(\frac{d_{p}}{d_{\text {out }}}\right)^{m} \cdot \bar{w}_{\text {out }}^{2},
$$

where $b$ is experimental parameter, $\mathrm{N} \cdot \mathrm{s}^{2} / \mathrm{m}^{4} ; m$ is a degree indicator, which depends on the angle of the confuser at the exit from the vortex tube; $d_{p}$ is inner diameter of pipe of vortex tube, $\mathrm{m}$; $d_{\text {out }}$ is diameter of the outlet branch pipe, $\mathrm{m}$; $\bar{w}_{\text {out }}$ is average speed flow at the outlet of the vortex tube, $\mathrm{m} / \mathrm{s}$.

The values of the parameter $b$ and the degree indicator $m$ for different angles of confuser at the exit from the vortex tube are given in the Table 2.

Table 2. The values of parameter $b$ and degree indicator $m$ for different angles of confuser at the exit from the vortex tube.

\begin{tabular}{|c|c|c|c|}
\hline Angles of confuser $\alpha,^{\circ}$ & $\leqslant 7.5$ & $\leqslant 15$ & $\leqslant 30$ \\
\hline Parameter $b, \mathrm{~N} \cdot \mathrm{s}^{2} / \mathrm{m}^{4}$ & 158.0 & 162.0 & 185.0 \\
\hline Degree indicator $m$ & 0.10 & 0.15 & 0.25 \\
\hline
\end{tabular}

Working gas exits from the cooled and heated ends of the vortex tube, respectively, after the diaphragm and the throttle valve. Hydraulic resistance of the section of the developed flow in the vortex tube:

$$
\Delta P_{d . f}=\frac{4 \cdot 0.0395 \cdot \rho \cdot \bar{w}_{d . f}^{2}}{\operatorname{Re}^{0.25}} \cdot l_{d . f},
$$

where $\rho$ is flow density; $\bar{w}_{d . f}$ is average speed flow on the section of developed flow, $\mathrm{m} / \mathrm{s} ; l_{d . f}$ is length of the developed flow, $\mathrm{m}$; Re $=\frac{\bar{w}_{d . f} \cdot d_{p}}{\nu}$ is Reynolds number; $d_{p}$ is inner diameter of pipe of the vortex tube, $\mathrm{m} ; \nu$ is coefficient of kinematic viscosity, $\mathrm{m}^{2} / \mathrm{s}$.

Hydraulic resistance of the centrifugal flow section:

$$
\Delta P_{c e n . f}=a_{1} c_{f} \rho \cdot \frac{\bar{w}^{2}}{2} f_{c}
$$

where $c_{f}$ is coefficient of complete friction of the flow with the surface,

$$
c_{f}=0,427\left(\lg \operatorname{Re}_{e n t}-0.407\right)^{-2.64} ;
$$


$\bar{w}$ is average speed of the jet, $\mathrm{m} / \mathrm{s} ; \bar{w}=\frac{\bar{w}_{e n t}+\bar{w}_{d . f}}{2} ; f_{c}$ is surface of contact of a flow with an internal surface of a case, $\mathrm{m}^{2} ; f_{c}=\pi d_{p} l_{c e n . f} ; l_{c e n . f}$ is length of part of the jet flow, $\mathrm{m} ; a_{1}$ is experimental parameter which takes into account the additional resistance on the surface of the contact of the cooled and heated flows:

$$
a_{1}=1+\frac{1}{\left(P_{\text {ent }}\right)^{0.1} \cdot \bar{w}_{\text {ent }}^{0.5}} \cdot\left(\frac{m_{h}}{m_{c}}\right)^{0.2} ;
$$

$P_{\text {ent }}$ is flow pressure at the entrance to the vortex tube, $\mathrm{Pa} ; m_{h}, m_{\mathrm{c}}$ are mass, respectively, of a heated and cooled flows, $\mathrm{kg}$.

Angle of disclosure of a jet $\alpha=\arctan 0.149=8.5^{\circ}$. Hence the length of the jet $l_{\text {jet }}=\frac{\frac{d_{p}}{2}-d_{e n t}}{\tan \alpha}, \mathrm{m}$, but on the other hand $l_{j e t}=\pi d_{p} n$, where $n$ is number of turns of the jet.

Then the length of part of the jet flow is determined by the dependence:

$$
\begin{aligned}
l_{\text {cen.f }} & =n \cdot \bar{d}_{j e t}=n \cdot \frac{\frac{d_{p}}{2}+d_{\text {ent }}}{2}=\frac{l}{\pi d_{p}} \cdot \frac{\frac{d_{p}}{2}+d_{e n t}}{2} \\
& =\frac{\frac{d_{p}}{2}-d_{e n t}}{0.149 \pi d} \cdot \frac{\frac{d_{p}}{2}+d_{e n t}}{2}=\frac{\frac{d_{p}^{2}}{4}-d_{e n t}^{2}}{0.289 \pi d_{p}} .
\end{aligned}
$$

Heat power of the vortex tube:

$$
Q^{\prime}=\Delta P \cdot V .
$$

The amount of heat needed to heat the required amount of flow $V$ from $t_{\text {ent }}$ to $t_{h}$, is determined from the equation:

$$
Q=V \cdot c_{g} \cdot\left(t_{h}-t_{\text {ent }}\right),
$$

where $V$ is the amount of gas heated, $\mathrm{m}^{3} / \mathrm{s} ; c_{g}$ is specific volumetric heat capacity of the heated flow, $\mathrm{kJ} /\left(\mathrm{m}^{3} \cdot \mathrm{K}\right)$.

Equating (17) and (18), one can determine the degree of heating of the working gas after the vortex tube:

$$
\begin{gathered}
\Delta P \cdot V=V \cdot c_{g} \cdot\left(t_{h}-t_{e n t}\right), \\
\Delta P=c_{g} \cdot \Delta t_{h}, \\
\Delta t_{h}=\frac{\Delta P}{c_{g}} .
\end{gathered}
$$

As can be seen from the above dependencies, the initial data for a mathematical model are parameters that, when working on a vortex tube on natural gas, can not be changed, since they have constant values in the range of changes in pressure and temperature that are characteristic for the transportation of natural gas. These include physical parameters of natural gas such as density, coefficient of kinematic viscosity, specific volumetric heat capacity. Since the transport of natural gas through gas distribution stations is also characterized by constant pressure, the average velocities at the sections of the vortex tube are also the input parameters.

For the possibility of controlling a mathematical model, in particular for the possibility of changing the degree of heating of natural gas at gas distribution stations, the geometric dimensions of the elements of the vortex tube are used, namely, the diameter and length of the pipe of the vortex tube, the diameters of the inlet and outlet of the vortex tube, length of the developed flow, length of a part of the jet flow and length of the jet.

Knowing these parameters for the conditions of natural gas transportation through the gas distribution station, according to the proposed advanced mathematical model of the natural gas heating process in the vortex tube, it is possible to determine the degree of heating of natural gas after the vortex tube, which would prevent the formation of crystalline hydrates within the gas pressure regulator. 


\section{Conclusions}

The thermodynamic and physical bases of the process of heating the compressed gases in a vortex tube are considered, which has allowed us scientifically substantiate and improve the mathematical model of heating of natural gas in a vortex tube.

The mathematical model of the process of heating natural gas in a vortex tube is developed, which allows determining the degree of heating of natural gas after passing a vortex tube.

[1] Sevastyanov R. V., Kalitina Ya. Yu. Energy efficiency of industrial enterprises of Ukraine and barriers to its implementation. Economic Bulletin of the Zaporizhzhya State Engineering Academy. 7, 144-154 (2014), (in Ukrainian).

[2] Analysis of the efficiency of energy use in developed foreign countries and dependence on their imports. Kyiv, Ministry of Energy and Coal Industry of Ukraine, NEC "Ukrenergo", Scientific and Technical Center for Electricity, 2015 (in Ukrainian).

[3] Voznyak O. T. Influence of interaction of jets on air distribution in the room. Bulletin of the Lviv Polytechnic National University "Heat Power Engineering. Environmental engineering. Automation". 432, 27-31 (2001), (in Ukrainian).

[4] Labay V., Dovbush O., Yaroslav V., Klymenko H. Mathematical modeling of a split-conditioner operation for evaluation of exergy efficiency of the R600A refrigerant application. Mathematical Modeling and Computing. 5 (2), 169-177 (2018).

[5] Zhelykh V., Kozak Ch., Savchenko O. Using of Thermosiphon Solar Collector in an air Heating System of Passive House. Pollack Periodica. 11 (2), 125-133 (2016).

[6] Zhelykh V., Savchenko O., Pashkevych V., Matusevych V. The geothermal ventilation of passive house. Budownictwo o zoptymalizowanym potencjale energetycznym. 2 (16), 145-150 (2015).

[7] Dombrovskyi O., Korsakaite D., Geletukha G., Savchuk S. What can bioenergy do to overcome gas crises. March 27, 2018. https://www.epravda.com.ua/publications/2018/03/27/635394/ (in Ukrainian).

[8] Savchenko O., Zhelykh V., Yurkevych Yu., Shapoval S., Kozak Kh. Using vortex tube for decreasing losses of natural gas in engineering systems of gas supply. Pollack Periodica. 13 (3), 241-250 (2018).

[9] Rattanongphisat W. The Development of Ranque-Hilsch Vortex Tubes: Computational Models. Industrial Technology Journal, Lampang Rajabhat University. 32, 40-51 (2010).

[10] Smith Eiamsa-ard, Pongjet Promvonge. Review of Ranque-Hilsch effects in vortex tubes. Renewable and Sustainable Energy Reviews. 12 (7), 1822-1842 (2008).

[11] CarrascalE., Sala J. M. Mass, energy, entropy and exergy rate balance in a Ranque-Hilsh vortex tube. Journal of technology and science education. 3 (3), 122-131 (2013).

[12] Balinsky I. S., Koval R., Banakhevych Yu., Kashina O. Patent of Ukraine for invention, No. 43673A, Gas distribution station, 17 December 2001, Bulletin No. 11 (in Ukrainian).

[13] Vortex tube and its use in the technique of separation of gas mixtures. Chemical and petroleum engineering. (Overview). Moscow, TsINTIHIMneftemash, 1983 (in Russian).

[14] Rudnik A. A., Kolomeyev V.M., Rozonyuk V.V., Grigil M. A. et al. Operation and Maintenance of Gas Distribution Stations of Main Gas Pipelines: Reference. Kyiv, Rostok (2003), (in Ukrainian). 


\title{
Математичне моделювання процесу нагрівання у вихровій трубі на газорозподільних станціях
}

\author{
Лабай В. Й., Савченко О. О., Желих В. М., Козак Х. Р. \\ Кафедра теплогазопостачання $i$ вентиляиї, \\ Інститут будівництва та інженеріӥ довкілля, \\ Національний університет "Львівсъка політехніка", \\ вул. С. Бандери, 12, Львів, 79013, Украӥна
}

У всіх галузях народного господарства України важливе місце займають питання енергоефективності та економії паливно-енергетичних ресурсів. Законодавчі зміни у галузях та наукові розробки вчених дозволяють зменшити енергетичну залежність України від імпортного палива. Одним із енергоощадних заходів під час транспортування природного газу є використання вихрової труби для нагрівання природного газу на газорозподільних станціях. Природний газ нагрівають перед процесом його редукування у регуляторі тиску газу щоб запобігти утворенню кристалогідратів всередині регулятора тиску газу. Складність впровадження такого заходу полягає у вибухо- та пожежонебезпечності природного газу, що унеможливлює проведення достатньої кількості експериментальних досліджень для визначення необхідних характеристик вихрової труби для роботи на газорозподільній станції. Тому для широкого впровадження вихрової труби на газорозподільних станціях необхідно розробити узагальнену математичну модель, яка би дала змогу описати процес нагрівання у вихровій трубі робочого тіла з різними теплофізичними параметрами. У статті розглянуто термодинамічні та фізичні основи процесу нагрівання стиснених газів у вихровій трубі та визначено основні показники, які впливають на роботу вихрової труби. Науково обгрунтовано та удосконалено математичну модель процесу нагрівання природного газу у вихровій трубі. Для удосконалення математичної моделі нагрівання природного газу у вихровій трубі визначено втрати динамічного тиску на кожній характерній ділянці вихрової труби та ступінь нагрівання в ній. Разом з тим запропонована математична модель дає змогу визначити теплову потужність вихрової труби та кількість теплоти, необхідної для нагрівання робочого тіла у вихровій трубі.

Ключові слова: прочес нагрівання, вихрова труба, газорозподільна станція, природний газ.

2000 MSC: $80 \mathrm{~A} 10 ; 80 \mathrm{~A} 20 ; 82 \mathrm{C} 40$

УДК: $621.6-032.31$ 